\title{
LAHAN POTENSIAL PERMUKIMAN DI KOTA SEMARANG
}

\author{
Study on Potential Settlement Land in Semarang City
}

\author{
Hala Haidir ${ }^{1}$, Iwan Rudiarto ${ }^{2}$
}

Diterima: 1 Februari 2019 Disetujui: 12 April 2019

\begin{abstract}
Abstrak: Pertambahan dan penyebaran pendudukan antar wilayah selalu mempunyai pengaruh terhadap permukiman, dimana untuk permukiman penduduk memerlukan lahan sedangkan lahan di perkotaan memiliki banyak kegiatan dan ketersediaannya terbatas. Keterbatasan lahan potensial permukiman tersebut sangat mempengaruhi arah penduduk dalam mencari tempat untuk bermukim. Penelitian ini bertujuan untuk mengkaji lahan potensial permukiman di Kota Semarang. Metode yang digunakan dalam penelitian ini adalah metode deskriptif kuantitatif dan deskriptif spasial yang terdiri dari analisis kesesuaian lahan permukiman (overlay dan pembobotan), analisis lahan potensial permukiman (buffer, overlay dan pembobotan ), analisis pertambahan penduduk, analisis daya dukung permukiman dan terakhir analisis distribusi penduduk. Hasil penelitian menunjukkan bahwa kecamatan yang paling banyak tersedia lahan potensial adalah Kecamatan Mijen dan secara total luas lahan potensial di Kota Semarang sebesar 7.006 Ha. Hasil dari lahan potensial tersebut menjadi tujuan untuk arahan distribusi penduduk bagi kecamatan yang tidak memiliki lahan potensial permukiman, antara lain tersebar di Kecamatan Semarang Barat, Kecamatan Tugu, Kecamatan Ngaliyan, Kecamatan Mijen, Kecamatan Gunung Pati, Kecamatan Tembalang, dan Kecamatan Pedurungan.
\end{abstract}

Kata Kunci: lahan potensial permukiman, pertambahan penduduk, distribusi penduduk

Abstract: The increase and spread of population between regions always have an impact on settlements, whereby settlements requires a land while land in acity has many activities and it is limited. These limited potential settelment lands greatly influence the direction of the population in finding a place to settle. This study aims to study on potential settlement land in Semarang City. The methods used are quantitative descriptive and spatial descriptive that consist of settlement land suitability analysis (overlaying and weighting), potential settlement land analysis (buffering, overlaying and weighting), population growth analysis, settlement carrying capacity analysis, and distribution of population analysis. The results showed that the most available sub-district of potential settelment land is Mijen Subdistrict and the total potential land area in Semarang City is 7,006 Ha. The results of the potential land are the destination for the direction of population distribution for sub-districts that do not have potential settelment land, among others are spread in West Semarang District, Tugu District, Ngaliyan District, Mijen District, Gunung Pati District, Tembalang District, and Pedurungan District.

\footnotetext{
${ }^{1}$ Program Studi Perencanaan Wilayah dan Kota, Universitas Indo Global Mandiri

${ }^{2}$ Departemen Perencanaan Wilayah dan Kota, Universitas Diponegoro
} 


\section{PENDAHULUAN}

Populasi global secara eksponensial meningkat sepanjang abad ke-20 dengan perkiraan pada tahun 2016 sekitar 7,4 miliar dan pada tahun 2100 meningkat menjadi 9,6 miliar (Chi \& Chak, 2018). Di negara yang sedang berkembang pertumbuhan suatu kota (urban growth) di ukur berdasarkan pertumbuhan penduduk yang berlangsung begitu cepat (Sriwinarti, 2005). Di Indonesia menurut data Word Bank, (2016) laju pertumbuhan penduduk yang tinggal di kota 4,1\% lebih cepat dari kota-kota yang ada di negara Asia lainnya dan diperkirakan pada tahun 2025 penduduk Indonesia yang akan tinggal di kota yaitu sebesar $68 \%$. Proses pertumbuhan perkotaan ini didorong oleh kekuatan aglomerasi yang terkait dengan daya tarik perkotaan untuk pekerjaan, dimana pekerjaan berpengaruh terhadap tempat tinggal dan menyebar sehingga terjadi kepadatan berlebih (Broitman \& Koomen, 2015).

Kota merupakan fenomena ekologi yang menjadi mesin utama pertumbuhan ekonomi dan tempat-tempat dimana bagian terbesar umat manusia berdiam (Newman \& Jennings, 2008 dalam La et al., 2011). Pertumbuhan kota yang ditandai dengan meningkatnya pertambahan jumlah penduduk sejajar dengan semakin meningkatnya kebutuhan tempat atau lahan untuk tempat tinggal serta tempat beraktivitas lainnya. Jika hal tersebut terjadi terus menerus mengakibatkan penurunan rasio lahan-manusia (landman ratio) dan menyebabkan peningkatan tekanan terhadap lahan (Baja, 2012).

Penentuan lahan atau lokasi yang sesuai untuk pertumbuhan perkotaan di wilayah marginal berdekatan dengan pembangunan berskala besar merupakan salah satu isu kritis dalam perencanaan kota (Aburas et al., 2017). Isu kritis tersebut antara lain adalah lokasi permukiman dimana sebagai unsur utama dan mencakup persentase yang jauh lebih besar dibandingkan dengan jenis penggunaan lahan lainnya serta sektor permukiman memegang peran penting dalam perekonomian nasional dan merupakan unsur dari kebijakan sosial nasional (Susanti, et al., 2016, Catanese \& Snyder, 1998). Namun, disisi lain dalam pemilihan lokasi permukiman banyak masyarakat yang tidak paham atau peduli dengan lahan yang ditempatinya. Contoh kasus tersebut terjadi di Kota Semarang yang merupakan Kota terbesar di Jawa Tengah dan sebagai Kota Metropolitan. Sehingga tidak heran jika jumlah penduduk Kota Semarang setiap tahunnya semakin meningkat secara alami maupun disebabkan oleh faktor migrasi. Rata-rata laju pertumbuhan penduduk Kota Semarang selama sepuluh tahun terakhir (2008-2017) yaitu sebesar 1,035 \% (BPS, 2018). Dengan besarnya laju pertumbuhan penduduk tersebut, maka semakin meningkat pula kebutuhan akan lahan untuk permukiman.

Dengan adanya sebuah tindakan dalam pendistribusian penduduk di lahan yang potensial untuk permukiman diharapkan dapat meminimalkan dampak negatif yang akan terjadi, dikarenakan penduduk merupakan elemen yang sangat penting dalam sebuah perencanaan wilayah dan kota dan sebagai inti dari pembangunan baik dari subjek maupun objek (Handayani \& Rudiarto, 2011). Pertumbuhan penduduk dan permukiman juga diperkirakan memberikan prediksi yang konsisten perubahan masa lalu dan dapat digunakan untuk memproyeksikan perubahan masa depan (Lee et al., 2016).

Penelitian mengenai lahan permukiman telah cukup banyak yang melakukan baik itu evaluasi maupun mencari kebutuhan lahan baru (potensial) akan tetapi variabel yang digunakan yakni berbeda-beda. Beberapa penelitian yang senada di antaranya dilakukan oleh Setyowati (2007) yaitu tujuan penelitiannya untuk mengevaluasi kesesuaian lahan permukiman dengan teknik Sistem Informasi Geografis (SIG) di Kota Semarang pada penelitian tersebut mencari kesesuaian lahan dengan membandingkan 10 variabel parameter kesesuaian lahan antara kondisi wilayah dengan kriteria yang telah ditentukan. Penelitian yang dilakukan oleh Satria \& Rahayu (2013) melakukan penelitian yang bertujuan mengevaluasi kesesuaian lahan permukiman namun hanya dibagian Selatan Kota 
Semarang. Syukur (2013) dalam penelitiannya yaitu bertujuan untuk menganalisa ketersediaan lahan permukiman bagi pertumbuhan penduduk perkotaan menggunakan sistem informasi geografis. Kajian dalam penelitian ini yaitu melihat ketersediaan lahan permukiman bagi pertumbuhan penduduk namun lahan yang dijadikan sebagai permukiman tidak dianalisis lebih lanjut yaitu hanya terdiri dari semak belukar, alangalang dan rawa serta guna tanah diambil berjarak $50 \mathrm{~m}$ dari tepi sungai dan 100 dari tepi/garis pantai. Nugraha, et al., (2014) meneliti dengan tujuan untuk menentukan lokasi potensial pengembangan kawasan perumahan dan permukiman (studi kasus kabupaten boyolali) dimana pada penelitian ini hanya menentukan lahan yang berpotensi untuk dijadikan lahan perumahan dan permukiman sedangkan untuk arahan distribusi penduduknya tidak dikaji dalam penelitian ini.

Dari beberapa hal di atas, penelitian ini bertujuan untuk mengetahui lahan potensial permukiman di Kota Semarang yang nantinya menjadi lahan untuk pendistribusian penduduk dimasa mendatang. Analisis yang dilakukan meliputi analisis kesesuaian lahan permukiman, analisis lahan potensial, analisis daya dukung permukiman dan analisis distribusi penduduk. Sehingga diharapkan dapat dijadikan masukan bagi para perencana kota, developer, masyarakat maupun stakeholder terkait dengan lahan potensial permukiman.

\section{METODE}

\section{Data}

Data yang digunakan yaitu menggunakan data sekunder bersumber kepada; 1). one map Kota Semarang terdiri dari data kelerengan, curah hujan, jenis tanah, potensi bencana, penggunaan lahan, sebaran sarana dan aksesibilitas, 2). BPN Kota Semarang yaitu data Nilai Tanah; 3). BPS Kota Semarang terdiri dari data kependudukan.

Tabel 1. Kebutuhan Data

\begin{tabular}{cl}
\hline No. & Data \\
\hline 1. & Curah hujan \\
2. & Kelerengan \\
3. & Jenis tanah \\
4. & Banjir \\
5. & Gerakan Tanah \\
6. & Sebaran Sarana Pendidikan \\
7. & Sebaran sarana Kesehatan \\
8. & Sebaran Sarana Perdagangan (Pasar) \\
3. & Jaringan jalan \\
10. & Citra Landsat \\
11. & Peta guna lahan \\
12. & Peta nilai lahan \\
13. & Penduduk time series (10 tahun terakhir) \\
\hline
\end{tabular}

Penelitian pendistribusian penduduk di lahan potensial permukiman ini menggunakan pendekatan kuantitatif dan deskriptif spasial, dimana semua data dan informasi yang dikumpulkan diolah dan dianalisis secara kuantitatif dan spasial dengan memanfaatkan teknologi Sistem Informasi Geografis (ArcGis). Analisis penelitian yang dilakukan yaitu:

1. Analisis Kesesuaian Lahan Permukiman 
Untuk menentukan lahan yang sesuai untuk permukiman dalam penelitian ini terdiri dari dua tahapan dan teknik analisis yaitu untuk mencari peruntukan kawasan budiaya (skor <125) mengunakan teknik pembobotan dan analisis kelerengan, kawasan konservasi, potensi bencana (gerakan tanah dan banjir), serta identfikasi penggunaan lahan eksisting menggunakan teknik Boolean.

a. Menggunakan teknik tumpang-tindih (Overlay) - Pembobotan.

Analisis kesesuaian lahan terdiri dari peta curah hujan, jenis tanah, dan kelerengan. Masing-masing akan diberikan bobot dan skor. Analisis ini nantinya akan menghasilkan peruntukan kawasan budidaya (Total Skor <125).

Tabel 2. Penilaian Kesesuaian Lahan Berdasarkan Sistem Pembobotan

\begin{tabular}{|c|c|c|c|c|c|c|}
\hline \multirow[b]{2}{*}{$\frac{a}{9}$} & \multicolumn{2}{|l|}{ Kelerengan } & \multicolumn{2}{|l|}{ Jenis Tanah } & \multicolumn{2}{|c|}{ Curah Hujan } \\
\hline & Kelerengan & 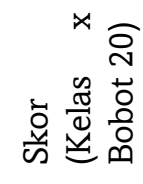 & Jenis Tanah & 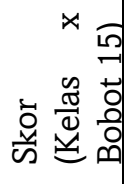 & $\begin{array}{l}\text { Curah } \\
\text { Hujan } \\
\text { (mm/hari) }\end{array}$ & 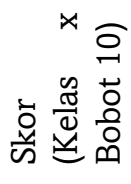 \\
\hline & $0-2 \%$ & 20 & $\begin{array}{l}\text { Aluvial, Tanah, Glei, Planossol, } \\
\text { Hidromorf Kelabu, Ltierite Air } \\
\text { Tanah }\end{array}$ & 15 & $<13,6$ & 10 \\
\hline & $2-5 \%$ & 40 & Latosol & 30 & $13,6-20,7$ & 20 \\
\hline & $5-15 \%$ & 60 & Brown Forest Soil, Non Calcic & 45 & $20,7-27,7$ & 30 \\
\hline & $15-40 \%$ & 80 & $\begin{array}{l}\text { Andosol, Laterictic Gromusol, } \\
\text { Podsolik }\end{array}$ & 60 & $27,7-34,8$ & 40 \\
\hline & $>40 \%$ & 100 & $\begin{array}{l}\text { Regosol, Litosol Organosol, } \\
\text { Renzine }\end{array}$ & 75 & $>34,8$ & 50 \\
\hline
\end{tabular}

Sumber : Sk Menteri Pertanian No 837/Kpts/Um/11/1980

b. Kesesuaian lahan menggunakan teknik tumpang-tindih (Overlay) - Boolean.

Teknik ini yaitu lanjutan dari analisis sebelumnya yang berguna untuk mem-filter lahan yang benar-benar sesuai untuk permukiman. Teknik ini menggunakan perkalian $1-0$ yang artinya; $0=$ tidak memenuhi kriteria $/$ tidak sesuai dan $1=$ memenuhi kriteria / sesuai. Untuk lebih jelasnya dapat dilihat pada Tabel 3.

2. Lahan Potensial Permukiman

Setelah didapatkan lahan yang sesuai untuk permukiman maka langkah selanjutnya yaitu menganalisis lahan yang sesuai tesebut menjadi lahan yang berpotensi (potensial) yang dinilai dari keterjangkauan sarana pelayanan, dekat dengan aksesibilitas, dan memiliki nilai lahan yang minimal. Ketiga hasil analisis tersebut akan di-overlay kembali dan diberikan skor 1 sampai 5 . Total skor nantinya akan dilakukan pengklasifikasian menjadi lima kelas, untuk mengetahui range pembagian kelas menggunakan metode sturgess ((nilai tertinggi - nilai terendah) / banyak kelas). Lebih jelasnya dapat dilihat pada Tabel 4.

a. Sarana perkotaan

Analisis ini menggunakan teknik Buffer (ArcGis). Lahan yang masuk kedalam lingkaran buffer maka dikatakan potensial, dan apabila diluar lingkaran maka tidak potensial.

b. Aksesibilitas (Kedekatan Dengan Jaringan Jalan)

Analisis ini menggunakan teknik Buffer (ArcGis) yang diambil dari jalan utama arteri dan kolektor, semakin dekat lahan yang masuk kedalam lingkaran buffer maka 
semakin potensial lahan tersebut dan sebaliknya semakin jauh dari jaringan jalan utama maka semakin tidak potensial.

c. Nilai Lahan

Berdasarkan data yang didapatkan nilai lahan di Kota Semarang sangat beragam, sehingga untuk mempermudah dalam mengidentifikasi dan menganalisis maka dilakukan pengklasifikasian menjadi lima kelas.

Tabel 3. Indikator Kesesuaian Lahan Teknik Boolean

\begin{tabular}{|c|c|c|c|}
\hline \multirow{2}{*}{ No } & \multirow[t]{2}{*}{ Data } & \multicolumn{2}{|c|}{ Kesesuaian } \\
\hline & & 0 & 1 \\
\hline \multirow[t]{3}{*}{1} & $\begin{array}{l}\text { Peta lahan sesuai untuk budidaya } \\
\text { peruntukan kawasan) }\end{array}$ & & \\
\hline & Skor $<125$ & & $\sqrt{ }$ \\
\hline & Skor $>125$ & $\sqrt{ }$ & \\
\hline \multirow[t]{3}{*}{2} & Peta Kelerengan & & \\
\hline & $>15 \%$ & $\sqrt{ }$ & \\
\hline & $<15 \%$ & & $\sqrt{ }$ \\
\hline \multirow[t]{2}{*}{3} & Peta Kawasan Lindung & & \\
\hline & $\begin{array}{l}\text { Lahan yang harus dilindungi (sempadan sungai, } \\
\text { hutan produksi tetap,dll) }\end{array}$ & $\sqrt{ }$ & \\
\hline \multirow[t]{4}{*}{4} & Bencana Banjir & & \\
\hline & Rendah & & $\sqrt{ }$ \\
\hline & Sedang & & $\sqrt{ }$ \\
\hline & Tinggi & $\sqrt{ }$ & \\
\hline \multirow[t]{4}{*}{5} & Bencana Gerakan Tanah & & \\
\hline & Rendah & & $\sqrt{ }$ \\
\hline & Sedang & & $\sqrt{ }$ \\
\hline & Tinggi & $\sqrt{ }$ & \\
\hline \multirow[t]{5}{*}{6} & Peta guna lahan saat ini & & \\
\hline & Terbangun (permukiman) & $\sqrt{ }$ & \\
\hline & Terbangun (non permukiman) & $\sqrt{ }$ & \\
\hline & Non terbangun (RTH) & $\sqrt{ }$ & \\
\hline & Non terbangun (pertanian, lahan kosong) & & $\sqrt{ }$ \\
\hline
\end{tabular}

Sumber: Muta'ali Lutfhi, 2012

Tabel 4. Radius Sarana Pelayanan Perkotaan

\begin{tabular}{|c|c|c|c|c|c|c|}
\hline \multirow[b]{2}{*}{$\begin{array}{l}\mathrm{N} \\
\mathrm{O}\end{array}$} & \multicolumn{2}{|c|}{ Sarana Perkotaan* } & \multicolumn{2}{|c|}{ Aksesibilitas } & \multirow[b]{2}{*}{ Nilai Lahan } & \multirow[b]{2}{*}{$\begin{array}{c}\mathrm{S} \\
\mathrm{k} \\
\mathrm{o} \\
\mathrm{r}\end{array}$} \\
\hline & $\begin{array}{l}\text { Jenis } \\
\text { Sarana }\end{array}$ & $\begin{array}{l}\text { Radius } \\
\text { (m) }\end{array}$ & $\begin{array}{l}\text { Radius } \\
\text { Jalan } \\
\text { Arteri } \\
\text { (m) }\end{array}$ & $\begin{array}{l}\text { Radius } \\
\text { Jalan } \\
\text { Kolektor } \\
(\mathrm{m})\end{array}$ & & \\
\hline 1 & SD & 1000 & $<1000$ & $<500$ & $<100.000$ & \\
\hline 2 & SLTP & $\begin{array}{l}1000 \\
3000\end{array}$ & $\begin{array}{l}1000- \\
2000\end{array}$ & $500-1000$ & $100.001-500.000$ & 4 \\
\hline 3 & SLTA & 3000 & $\begin{array}{l}2000- \\
3000\end{array}$ & $1000-1500$ & $500.001-1.000 .000$ & 3 \\
\hline 4 & Kesehatan & & $\begin{array}{l}3000- \\
4000\end{array}$ & $1500-2000$ & $\begin{array}{l}1.000 .001- \\
1.500 .000\end{array}$ & 2 \\
\hline 5 & Pasar & 3000 & $>4000$ & $>2000$ & $>1.500 .000$ & 1 \\
\hline
\end{tabular}

Sumber: *"SNI-1728-1989 
3. Proyeksi Penduduk

Kota Semarang dalam memperkirakan penduduk masa yang akan datang termasuk kedalam kota/kabupaten yang menggunakan metode geometrik. Dimana asumsi yang digunakan pada metode ini yaitu laju pertumbuhan (rate of growth) penduduk adalah konstan atau sama setiap tahunnya $\mathrm{r}(\%)$ atau menggunakan dasar bunga majemuk.

$$
\mathrm{Pt}=\mathrm{Po}(1+\mathrm{r}) \mathrm{t}
$$

Keterangan :

$$
\begin{aligned}
& \mathrm{Pt}=\text { Penduduk pada tahun } \mathrm{n} \\
& \mathrm{Po}=\text { Peduduk pada tahun awal } \\
& \mathrm{r}=\text { Angka pertumbuhan penduduk }(\mathrm{r}) \\
& \mathrm{n}=\text { Waktu dalam tahun ( priode proyeksi) }
\end{aligned}
$$

4. Daya Dukung Permukiman

Daya dukung wilayah untuk permukiman dapat diartikan sebagai kemampuan wilayah dalam menyediakan lahan permukiman guna manampung jumlah penduduk tertentu untuk bertempat tinggal secara layak (Muta'ali, 2015). Formula yang digunakan dalam analisis ini yaitu adalah sebagai berikut:

Keterangan :

$$
\mathrm{DDPm}=(\mathrm{LPm} / \mathrm{JP}) / \alpha
$$

$$
\begin{array}{ll}
\mathrm{DDPm} & =\text { daya dukung permukiman } \\
\mathrm{JP} & =\text { jumlah penduduk } \\
\alpha & =\text { koefisien luas kebutuhan ruang } / \text { kapita }\left(\mathrm{m}^{2} / \mathrm{kapita}\right) \\
& \text { Menurut SNI 03-1733-2004 sebesar } 26 \mathrm{~m}^{2} \\
\mathrm{LPm} & =\text { luas lahan yang layak untuk permukiman } \mathrm{m}^{2}
\end{array}
$$

5. Disitribusi Penduduk

Arahan distribusi penduduk dikaji berdasarkan kelas lahan potensial, luas lahan dan jarak antar pusat kecamatan. Total dari skor per kecamatan akan dibagi menjadi tiga klasifikasi menggunakan metode sturgess ((skor kecamatan tertinggi - skor kecamatan terendah)/3). Klasifikasi tersebut berupa pilihan untuk arahan distribusi penduduk teridiri dari; Pilihan 1 (P1) dan Pilihan 2 (P2).

Tabel 5. Matriks Penilaian Arahan Distribusi Penduduk

\begin{tabular}{llllllllll}
\hline \multirow{2}{*}{ No } & \multicolumn{2}{l}{$\begin{array}{l}\text { Lahan Potensial } \\
\text { (Bobot 40\%) }\end{array}$} & \multicolumn{4}{c}{$\begin{array}{l}\text { Luas Lahan } \\
\text { (Bobot 30\%) }\end{array}$} & \multicolumn{3}{c}{$\begin{array}{l}\text { Jarak } \\
\text { (Bobot 30\%) }\end{array}$} \\
\cline { 2 - 11 } & Potensial & Nilai & Skor* & Ha & Nilai & Skor* & Km & Nilai & Skor* \\
\hline 1 & Potensial 1 & 3 & 1,2 & $>300$ & 3 & 0,9 & $<5$ & 3 & 0,9 \\
2 & Potensial 2 & 2 & 0,8 & $100-300$ & 2 & 0,6 & $5-10$ & 2 & 0,6 \\
3 & Potensial 3 & 1 & 0,4 & $<100$ & 1 & 0,3 & $>10$ & 1 & 0,3 \\
\hline
\end{tabular}

*keterangan $=$ Nilai $\mathrm{x}$ Bobot

\section{HASIL DAN PEMBAHASAN}

\section{Kesesuaian Lahan Permukiman}

Kepadatan perumahan terjadi hampir pada semua wilayah perkotaan dan umumnya lebih rendah saat permintaan tempat tinggal baru tinggi dan jumlah lahan terbatas (Broitman \& Koomen, 2015). Sama halnya dengan perkembangan kota Semarang yang selalu mengalami peningkatan semenjak maraknya pengembang perumahan (develover). Pada awalnya pengadaan rumah merupakan monopoli pemerintah melalui perumnas, 
namun seiring berjalannya waktu pertumbuhan penduduk berbanding lurus dengan kebutuhan lahan permukiman maka pengadaan rumah dijalankan dengan swastanisasi dan semakin berkembang serta meluas ke segala arah (Setyowati, 2007). Hal tersebut tidak bisa dilakukan secara terus menerus jika lahan permukiman tidak sesuai dengan kriteria yang telah ditetapkan, maka akan menyebabkan kerusakan lahan maupun kerugian materil maupun non materil. Salah satu fenomena yang terjadi yaitu di bagian Selatan Kota Semarang berdasarkan penelitian Satria \& Rahayu (2013) lebih dari setengah lahan tidak sesuai dengan ketentuan untuk lahan permukiman yaitu sebanyak 50,9\%, hal tersebut dikarenakan lahan permukiman berada pada kawasan lindung dan kawasan penyangga, adapun variabel yang digunakan dalam penelitian tersebut adalah kelerengan, lokasi banjir, gerak tanah dan tingkat erosi.

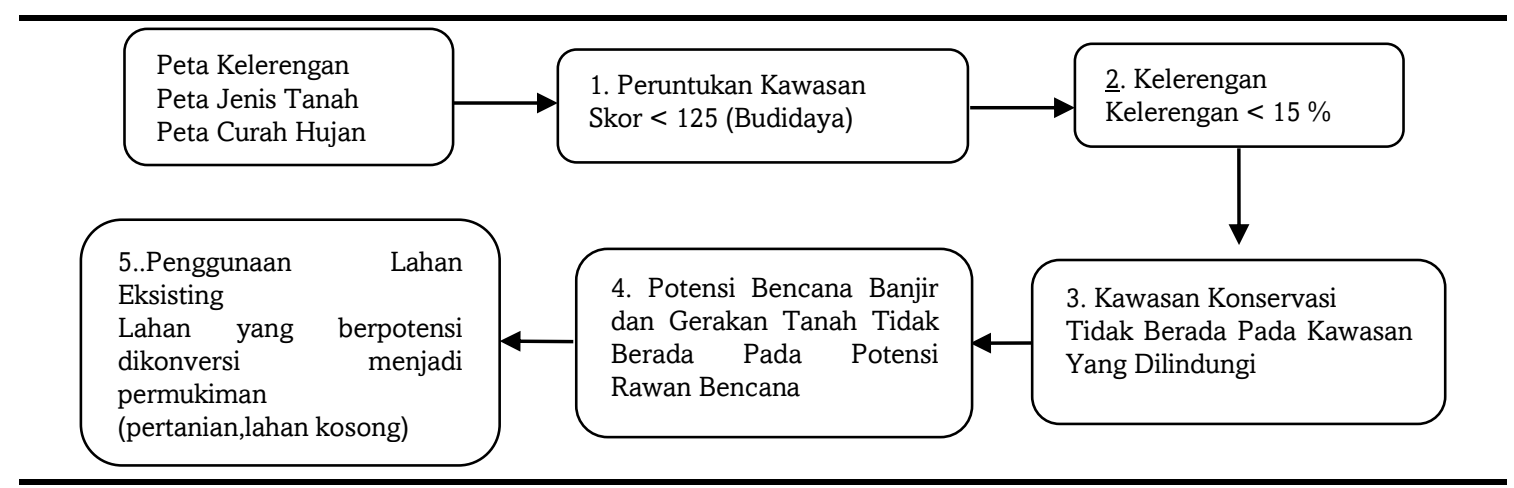

Gambar 1. Bagan Alir Analisis Kesesuaian Lahan Permukiman

Tabel 6. Kesesuaian Lahan Permukiman Kota Semarang

\begin{tabular}{|c|c|c|c|c|c|}
\hline No & Hasil Analisis & Peruntukan Kawasan & Keterangan & $\begin{array}{l}\text { Luas } \\
(\mathrm{Ha})\end{array}$ & $\begin{array}{l}\text { Persentase } \\
(\%)\end{array}$ \\
\hline \multirow[t]{3}{*}{1.} & \multicolumn{3}{|l|}{ Peruntukan Kawasan } & $38.944,48$ & 100,00 \\
\hline & \multirow{2}{*}{$\begin{array}{l}\text { Kelerengan, Jenis } \\
\text { Tanah dan Curah } \\
\text { Hujan }\end{array}$} & Skor $<125$ & Sesuai & $37.787,85$ & 97,03 \\
\hline & & Skor $>125$ & Tidak Sesuai & $1.156,63$ & 2,97 \\
\hline \multirow[t]{3}{*}{2.} & \multicolumn{3}{|c|}{ Identifikasi Kelerengan } & $37.787,85$ & 100,00 \\
\hline & \multirow[t]{2}{*}{ Skor $<125$} & Lereng $<15 \%$ & Sesuai & $36.892,35$ & 97,63 \\
\hline & & Lereng $>15 \%$ & Tidak Sesuai & 895,50 & 2,37 \\
\hline \multirow[t]{3}{*}{3} & \multicolumn{3}{|c|}{ Identifikasi Kawasan Konservasi } & $36.892,35$ & 100,00 \\
\hline & \multirow[t]{2}{*}{$<15 \%$} & Non Konservasi & Sesuai & $33.005,53$ & 89,46 \\
\hline & & Konservasi & Tidak Sesuai & $3.886,82$ & 10,54 \\
\hline \multirow[t]{3}{*}{4} & \multicolumn{3}{|l|}{ Potensi Bencana Banjir } & $33.005,53$ & 100,00 \\
\hline & \multirow[t]{2}{*}{ Non Konservasi } & $\begin{array}{l}\text { Tingkat Kerawan } \\
\text { Rendah hingga Sedang }\end{array}$ & Sesuai & $25.512,08$ & $77,30 \%$ \\
\hline & & $\begin{array}{l}\text { Tingkat Kerawan } \\
\text { Tinggi }\end{array}$ & Tidak Sesuai & $7.493,45$ & 22,70 \\
\hline \multirow[t]{3}{*}{5} & \multicolumn{3}{|c|}{ Potensi Bencana Gerakan Tanah } & $25.512,08$ & 100,00 \\
\hline & $\begin{array}{lr}\text { Tingkat } & \text { Kerawan } \\
\text { Bencana } & \text { Banjir }\end{array}$ & $\begin{array}{l}\text { Tingkat Kerawan } \\
\text { Rendah hingga Sedang }\end{array}$ & Sesuai & $23.299,71$ & 91,33 \\
\hline & $\begin{array}{l}\text { Rendah } \\
\text { Sedang }\end{array}$ & $\begin{array}{l}\text { Tingkat Kerawan } \\
\text { Tinggi }\end{array}$ & Tidak Sesuai & $2.212,37$ & 8,67 \\
\hline 6 & \multicolumn{3}{|c|}{ Identifikasi Penggunaan Lahan Eksisting } & $23.299,72$ & 100,00 \\
\hline
\end{tabular}




\begin{tabular}{|c|c|c|c|c|c|}
\hline No & Hasil Analisis & Peruntukan Kawasan & Keterangan & $\begin{array}{l}\text { Luas } \\
\text { (Ha) }\end{array}$ & $\begin{array}{l}\text { Persentase } \\
(\%)\end{array}$ \\
\hline & $\begin{array}{ll}\text { Tingkat } & \text { Kerawan } \\
\text { Bencana } & \text { Gerakan }\end{array}$ & Non Terbangun & Sesuai & $7.451,84$ & 31,98 \\
\hline & $\begin{array}{l}\text { Tanah Rendah hingga } \\
\text { Sedang }\end{array}$ & Terbangun & Tidak Sesuai & $15.847,88$ & $68,02 \%$ \\
\hline
\end{tabular}

Dalam penentuan lahan yang potensial untuk permukiman penelitian ini terlebih dahulu mengkaji analasis kesesuaian lahan. Untuk penelitian kesesuaian lahan permukiman sebelumnya telah banyak dilakukan dengan kombinasi variabel yang berbeda-beda. Seperti penelitian yang dilakukan oleh Samsidar et al., (2012) ada 10 (sepuluh) parameter penentu kelas kesesuaian lahan untuk permukiman yaitu: daya dukung lahan, lereng, posisi jalur patahan, kekuatan batuan, kembang kerut tanah, sistem drainase, kedalaman air tanah, erosi, bahaya longsor dan banjir. Menurut Umar et al., (2017) variabel kesesuaian lahan dikaji berdasarkan Kelerengan, banjir, drainase, batuan krikil, tekstur, dan kedalaman efektif. Menurut Syukur (2013) kesesuaian lahan permukiman dikaji berdasarkan variabel zona drainase, zona banjir, zona lereng permukaan, zona tekstur tanah, zona batuan, zona jenis efektif tanah dan zona erosi.

Namun dalam penelitian ini kesesuaian lahan permukiman ditinjau dari peruntukan kawasan, kelerengan, kawasan konservasi, potensi bencana banjir, potensi bencana gerakan tanah dan penggunaan lahan eksisting dengan menggunakan pembobotan untuk analisis peruntukan lahan dan analisis lainnya menggunakan teknik bolean. Berdasarkan variabel dan teknik analisis tersebut didapatkan hasil analisis kesesuaian lahan permukiman (sesuai tahap akhir) yaitu sebesar 7.451,84 Ha atau sekitar 19,13\% dari luas total Kota Semarang.

\section{Lahan Potensial Permukiman}

Menurut Nugraha et al., (2014) dalam mempertimbangkan potensi lahan untuk pengembangan kawasan perumahan dan permukiman selain berdasarkan kemiringan lereng, kerawanan bencana, kemampuan tanah, perubahan lahan, ketersedian air tanah dan pdam, juga mengkaji aksesbilitas, jarak terhadap pusat perdagangan dan fasilitas pelayanan umum. Sama dengan penelitian ini untuk lahan potensial dikaji berdasarkan aksesibilitas, radius sarana pelayanan dan ditambah dengan variabel nilai lahan dimana menurut Pupitasari \& Pradoto (2013) nilai lahan merupakan salah satu faktor yang mempengaruhi perubahan guna lahan dan pola perkembangan permukiman, semakin dipinggir jauh lebih rendah dibanding pusat kota sehingga mampu menarik penduduk untuk pindah ke daerah pinggiran.

Tabel 7. Skor Lahan Potensial Permukiman

\begin{tabular}{llrrr}
\hline No & Variabel & Skor & Luas (Ha) & Persentase (\%) \\
\hline A. & \multicolumn{2}{c}{ Jumlah Sarana } & 7.4 & 100,00 \\
1 & 0 & Pelayanan Perkotaan & 51,84 & 2,88 \\
2 & 1 & - & 214,89 & 3,19 \\
3 & 2 & 1 & 237,92 & 14,47 \\
4 & 3 & 2 & $1.078,05$ & 30,38 \\
5 & 4 & 3 & $2.263,67$ & 31,87 \\
6 & 5 & 4 & $2.375,19$ & 17,21 \\
\hline B. & Aksesibilitas & 5 & $1.282,11$ & 100,000 \\
1 & Sangat Jauh & 5 & $7.451,84$ & 0,004 \\
2 & Jauh & 4 & 0,32 & 7,722 \\
3 & Sedang & 4 & 575,41 & 19,607 \\
\hline
\end{tabular}




\begin{tabular}{lllrr}
\hline 4 & Dekat & 2 & $2.919,10$ & 39,173 \\
5 & Sangat Dekat & 1 & $2.495,94$ & 33,494 \\
\hline C. & Nilai Lahan & & $7.451,84$ & 100.00 \\
1 & $<100.000$ & 5 & $1.485,13$ & 19,93 \\
2 & $100.001-500.000$ & 4 & $5.180,62$ & 69,52 \\
3 & $500.001-1.000 .000$ & 4 & 380,24 & 5,10 \\
4 & $1.000 .001-1.500 .000$ & 2 & 345,84 & 4,64 \\
5 & $>1.500 .000$ & 1 & 60,00 & 0,81 \\
\hline
\end{tabular}

Dari hasil analisis kesesuaian lahan permukiman akan dianalisis kembali untuk mendapatkan lahan yang potensial untuk permukiman dinilai berdasarkan kedekatan dengan sarana pelayanan kota (SD, SLTP, SLTA, Puskesmas dan Balai Pengobatan serta pasar), kedekatan dengan aksesibilitas (jalan arteri dan jalan kolektor) dan memiliki nilai lahan rendah. Untuk sarana dan aksesibilitas menggunakan teknik buffering dengan radius masing-masing seperti yang telah ditetapkan. Sedangkan untuk nilai lahan yaitu menggunakan range atau interval.

Tabel 8. Klasifikasi Lahan Potensial Permukiman Kota Semarang

\begin{tabular}{lllll}
\hline Kelas & Keteragan & Total Skor & $\begin{array}{l}\text { Luas } \\
(\mathrm{Ha})\end{array}$ & $\begin{array}{l}\text { Persentase } \\
(\%)\end{array}$ \\
\hline I & Tidak Potensial & $4-6$ & 307,05 & 4,12 \\
II & Kurang Potensial & $6-8$ & 138,74 & 1,86 \\
III & Cukup Potensial & $8-10$ & $1.324,69$ & 17,78 \\
IV & Potensial & $10-12$ & $3.555,92$ & 47,72 \\
V & Sangat Potensial & $12-15$ & $2.125,45$ & 28,52 \\
\hline \multicolumn{5}{c}{ Total } \\
\hline
\end{tabular}

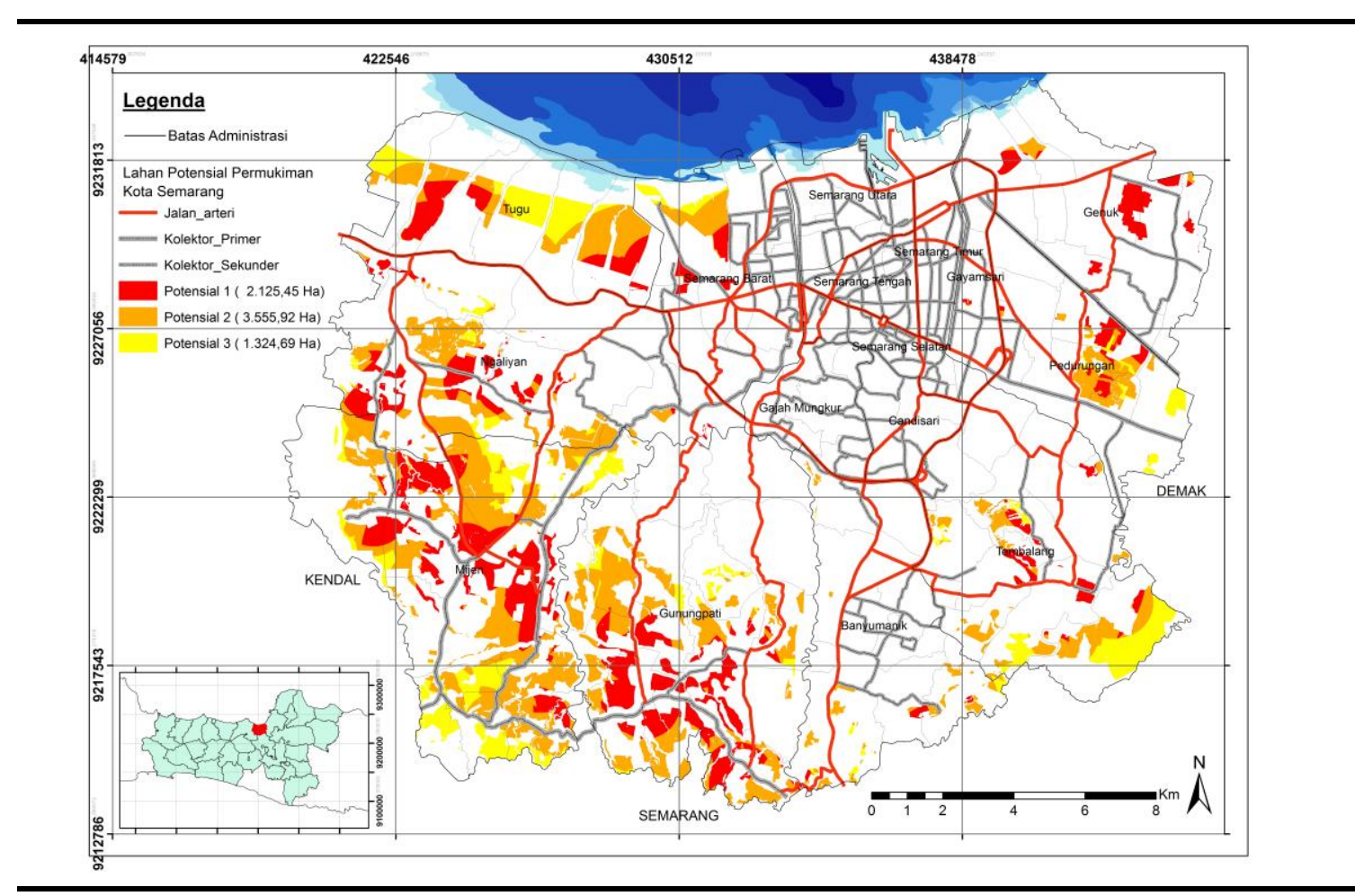

Gambar 2. Lahan Potensial Permukiman di Kota Semarang 
Tabel 9. Daya Dukung Permukiman Kota Semarang

\begin{tabular}{|c|c|c|c|c|c|c|c|c|}
\hline $\begin{array}{l}\mathrm{N} \\
\mathrm{o}\end{array}$ & Kecamatan & $\begin{array}{l}\text { Laju Per- } \\
\text { tumbuhan } \\
\text { Penduduk } \\
\text { (r) }\end{array}$ & $\begin{array}{l}\text { Penduduk } \\
\text { Tahun } \\
\text { Eksisting } \\
2018 \\
\text { (Jiwa) }\end{array}$ & $\begin{array}{l}\text { Penduduk } \\
\text { Tahun } \\
\text { Proyeksi } \\
2038 \\
\text { (Jiwa) }\end{array}$ & $\begin{array}{l}\text { Pertambah- } \\
\text { an } \\
\text { Penduduk } \\
2038 \\
\text { (Jiwa) }\end{array}$ & $\begin{array}{l}\text { Lahan } \\
\text { Potensial } \\
\text { (m2) }\end{array}$ & $\begin{array}{l}\text { Kebutuhan } \\
\text { Lahan } \\
\text { Jiwa/m2 }\end{array}$ & $\begin{array}{l}\left({ }^{\star}\right) \\
\text { Ket }\end{array}$ \\
\hline 1 & Mijen & 0,042 & 73.871 & 168.408 & 56.871 & 23.279 .315 & 1.478 .646 & + \\
\hline 2 & Gunung Pati & 0,042 & 92.464 & 210.112 & 70.729 & 13.727 .048 & 1.838 .954 & + \\
\hline 3 & Banyumanik & 0,026 & 150.598 & 253.353 & 58.021 & 1.405 .056 & 1.508 .546 & - \\
\hline 4 & Gajahmungkur & 0,014 & 70.493 & 93.359 & 12.235 & - & 318.110 & - \\
\hline 5 & $\begin{array}{l}\text { Semarang } \\
\text { Selatan }\end{array}$ & 0,003 & 85.712 & 90.998 & 2.683 & - & 69.758 & - \\
\hline 6 & Candisari & 0,007 & 86.260 & 99.360 & 6.782 & - & 176.332 & - \\
\hline 7 & Tembalang & 0,039 & 182.633 & 394.603 & 126.149 & 6.634 .396 & 3.279 .874 & + \\
\hline 8 & Pedurungan & 0,022 & 203.607 & 316.901 & 62.887 & 3.417 .296 & 1.635 .062 & + \\
\hline 9 & Genuk & 0,037 & 114.656 & 237.511 & 72.489 & 1.840 .554 & 1.884 .714 & - \\
\hline 10 & Gayamsari & 0,015 & 81.977 & 110.797 & 15.493 & 33.781 & 402.818 & - \\
\hline 11 & $\begin{array}{l}\text { Semarang } \\
\text { Timur }\end{array}$ & 0,001 & 82.975 & 85.161 & 1.100 & - & 28.600 & - \\
\hline 12 & $\begin{array}{l}\text { Semarang } \\
\text { Utara }\end{array}$ & 0,011 & 139.244 & 172.113 & 17.305 & - & 449.930 & - \\
\hline 13 & $\begin{array}{l}\text { Semarang } \\
\text { Tengah }\end{array}$ & 0,004 & 75.257 & 81.584 & 3.227 & - & 83.902 & - \\
\hline 14 & $\begin{array}{l}\text { Semarang } \\
\text { Barat }\end{array}$ & 0,008 & 172.675 & 202.270 & 15.382 & 2.382 .557 & 399.932 & + \\
\hline 15 & Tugu & 0,029 & 36.033 & 63.630 & 15.747 & 8.987 .824 & 409.422 & + \\
\hline 16 & Ngaliyan & 0,030 & 142.143 & 257.584 & 66.237 & 8.352 .568 & 1.722 .162 & + \\
\hline \multicolumn{2}{|c|}{ Total } & & 1.790 .599 & 1.995 .809 & 2.837 .744 & 70.060 .394 & 15.686 .762 & + \\
\hline
\end{tabular}

$\left({ }^{\star}\right)$ Keterangan : Tanda $(+)=$ Tertampung;

Tanda $(-)=$ Tidak Tertampung

Hasil penelitian berdasarkan Tabel 9 dan Gambar 2 Kecamatan yang masih banyak memiliki daya dukung untuk pengembangan permukiman dimasa yang akan datang yaitu Kecamatan Mijen dengan luas lahan potensial 23.279.315 $\mathrm{m}^{2}$ dan kebutuhan lahan sebesar 1.478.646 jiwa $/ \mathrm{m}^{2}$ sehingga memiliki sisa lahan seluas $+21.800 .669 \mathrm{~m}^{2}$ dan Kecamatan Gunung Pati dengan luas lahan potensial $13.727 .048 \mathrm{~m}^{2}$ dan kebutuhan lahan sebesar 1.838.954 jiwa $/ \mathrm{m}^{2}$ sehingga masih bisa menampung seluas $+11.888 .094 \mathrm{~m}^{2}$. Kecamatan yang memiliki lahan potensial namun masih kekurangan lahan permukiman sehingga dikategorikan tidak tertampung antara lain; Kecamatan Banyumanik kekurangan lahan sekitar -103.490 $\mathrm{m}^{2}$, Kecamatan Genuk kekurangan lahan sekitar $-44.160 \mathrm{~m}^{2}$; dan Kecamatan Gayamsari memiliki kekurangan lahan sekitar $-369.037 \mathrm{~m}^{2}$. Kecamatan yang tidak tertampung penduduknya di masa mendatang dikarenakan tidak memiliki lahan potensial permukiman namun jumlah penduduk bertambah adalah Kecamatan Gajah Mungkur, Kecamatan Semarang Selatan, Kecamatan Candi Sari, Kecamatan Semarang Timur, Kecamatan Semarang Utara dan Kecamatan Semarang Tengah. Namun secara umum di Kota Semarang pada akhir tahun 2038 masih bisa menampung penuduk di karenakan memiliki sisa lahan potensial untuk permukiman seluas $+55.500 .264 \mathrm{~m}^{2}$.

\section{Distribusi Penduduk}

Peningkatan jumlah penduduk bisa disebabkan oleh pertumbuhan alami maupun urbanisasi. Peningkatan jumlah penduduk alami dan peningkatan urbanisasi berbanding lurus, dimana jika tidak terkendali maka akan menimbulkan berbagai masalah (Nursyahbani \& Pigawati 2015). Oleh karena itu penelitian ini melakukan kajian arahan 
pendistribusian penduduk Kabupaten Semarang untuk tahun yang akan datang dilihat berdasarkan daya dukung permukiman dan ketersediaan lahan dimasa yang akan datang.

Tabel 10. Arahan Distribusi Penduduk Kota Semarang

\begin{tabular}{|c|c|c|c|c|c|c|c|c|c|c|}
\hline \multirow[b]{2}{*}{$\begin{array}{l}\mathrm{N} \\
\mathrm{O}\end{array}$} & \multicolumn{9}{|c|}{ Kecamatan Asal } & \multirow[b]{2}{*}{ Kecamatan Tujuan } \\
\hline & 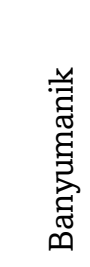 & 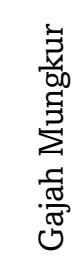 & 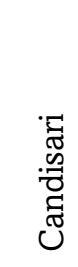 & 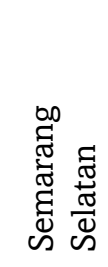 & 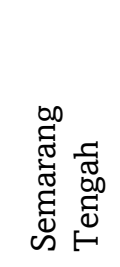 & 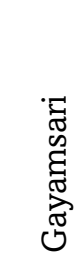 & 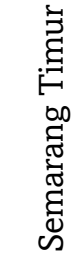 & 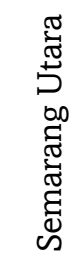 & 岂 & \\
\hline 1 & P2 & P2 & P2 & P2 & P2 & P2 & P2 & P1 & P2 & Tugu \\
\hline 2 & $\mathrm{P} 2$ & $\mathrm{P} 1$ & $\mathrm{P} 2$ & P1 & $\mathrm{P} 1$ & $\mathrm{P} 2$ & $\mathrm{P} 2$ & $\mathrm{P} 1$ & $\mathrm{P} 2$ & Semarang Barat \\
\hline 3 & $\mathrm{P} 2$ & $\mathrm{P} 1$ & $\mathrm{P} 2$ & $\mathrm{P} 2$ & $\mathrm{P} 2$ & $\mathrm{P} 2$ & P2 & $\mathrm{P} 2$ & $\mathrm{P} 2$ & Ngaliyan \\
\hline 4 & $\mathrm{P} 1$ & $\mathrm{P} 1$ & $\mathrm{P} 1$ & $\mathrm{P} 1$ & $\mathrm{P} 1$ & $\mathrm{P} 1$ & $\mathrm{P} 1$ & $\mathrm{P} 1$ & $\mathrm{P} 1$ & Mijen \\
\hline 5 & $\mathrm{P} 1$ & $\mathrm{P} 1$ & $\mathrm{P} 1$ & P1 & $\mathrm{P} 2$ & $\mathrm{P} 2$ & $\mathrm{P} 2$ & P2 & $\mathrm{P} 2$ & Gunung Pati \\
\hline 6 & $\mathrm{P} 1$ & $\mathrm{P} 1$ & $\mathrm{P} 1$ & $\mathrm{P} 1$ & $\mathrm{P} 1$ & $\mathrm{P} 2$ & $\mathrm{P} 1$ & $\mathrm{P} 2$ & $\mathrm{P} 1$ & Tembalang \\
\hline 7 & P2 & P2 & $\mathrm{P} 2$ & P2 & P2 & $\mathrm{P} 1$ & P2 & P2 & $\mathrm{P} 1$ & Pedurungan \\
\hline
\end{tabular}

Berdasarkan Tabel 10 dan Gambar 3 Pendistribusian dilakukan pada kecamatan yang tidak memiliki ketersedian lahan potensial permukiman ke kecamatan yang masih memiliki lahan potensial yang terlebih dahulu mencukupi kebutuhan kecamatan itu sendiri. Dalam penelitian ini pertimbangan dalam arahan pendistribusian penduduk adalah kelas lahan potensial, luas lahan potensial dan jarak antar pusat kecamatan. Berdasarkan tiga variabel yang disebutkan diatas maka didapatkan hasil berupa alternatif atau pilihan untuk arahan distribusi penduduk teridiri dari; Pilihan 1 (P1), Pilihan 2 (P2).

\section{Diskusi}

Lahan potensial permukiman di Kota Semarang untuk 20 tahun yang akan datang secara umum masih tersedia, walaupun beberapa kecamatan yang berada dipusat kota harus didistribusikan penduduknya ke kecamatan yang masih memiliki lahan potensial permukiman yakni sebagian besar kecamatan yang berada dipinggiran Kota Semarang. Lahan potensial permukiman pada penelitiaan ini yaitu dihasilkan berdasarkan kelerengan, jenis tanah, curah hujan, kawasan konservasi, bencana banjir, bencana longsor dan penggunaan lahan eksisting, serta dilihat berdasarkan kedekatan dengan sarana pelayanan perkotaan, kedekatan dengan aksesibilitas dan nilai lahan. Senada dengan penelitian sebelumnya yang dilakukan oleh Setyowati (2007) dan Satria \& Rahayu (2013) namun peneliti sebelumnya hanya sebatas kesesuaian lahan permukiman (aspek fisik) tidak mengkaji kedekatan dengan sarana, aksesibilitas dan nilai lahan sebagai bahan pertimbangan untuk lahan permukiman. Satria dan Rahayu (2013) mengkaji kesesuaian lahan permukiman namun hanya di bagian Selatan Kota Semarang dengan hasil lahan yang sesuai untuk permukiman paling banyak terdapat di Kecamatan Gunung Pati, kemudian Kecamatan Banyumanik dan Kecamatan Tembalang. Sedangkan jika dibandingkan dengan penelitian ini Kecamatan Banyumanik untuk 20 tahun yang akan datang tidak lagi memiliki lahan yang potensial untuk permukiman. Penelitian lainnya yang serupa yaitu dilakukan oleh Syukur (2013), namun demikian selain berbeda lokasi studi untuk menentukan lahan yang potensial penelitian tersebut hanya mengkategorikan semak belukar, alang-alang dan rawa serta guna tanah (berjarak $50 \mathrm{~m}$ dari tepi sungai dan 100 dari tepi/garis pantai) sebagai lahan potensial permukiman tanpa dikaji lebih lanjut kesesuaian lahannya dan kebutuhan lahan untuk setiap 4 orang penduduk memerlukan luas tanah $300 \mathrm{~m}^{2}$ sedangkan pada penelitian ini yaitu menggunakan standar SNI 03-1733-2004 untuk lahan permukiman seluas $26 \mathrm{~m}^{2} /$ kapita. Terakhir jika dibandingkan dengan penelitian terdahulu yang dilakukan oleh Nugraha et al., (2014) untuk menentukan lokasi potensial pengembangan kawasan perumahan dan permukiman yaitu sama-sama mengkaji aspek fisik dan sarana pelayanan umum 
namun tidak mengkaji nilai lahan. Hasil dari penelitiannya juga tidak mengkaji arahan pendistribusian penduduk yang berada di lahan yang tidak potensial ke lahan yang potensial, penelitiannya hanya melihat lahan yang tidak bepotensi, cukup berpotensi, kurang berpotensi dan sangat berpotensi.

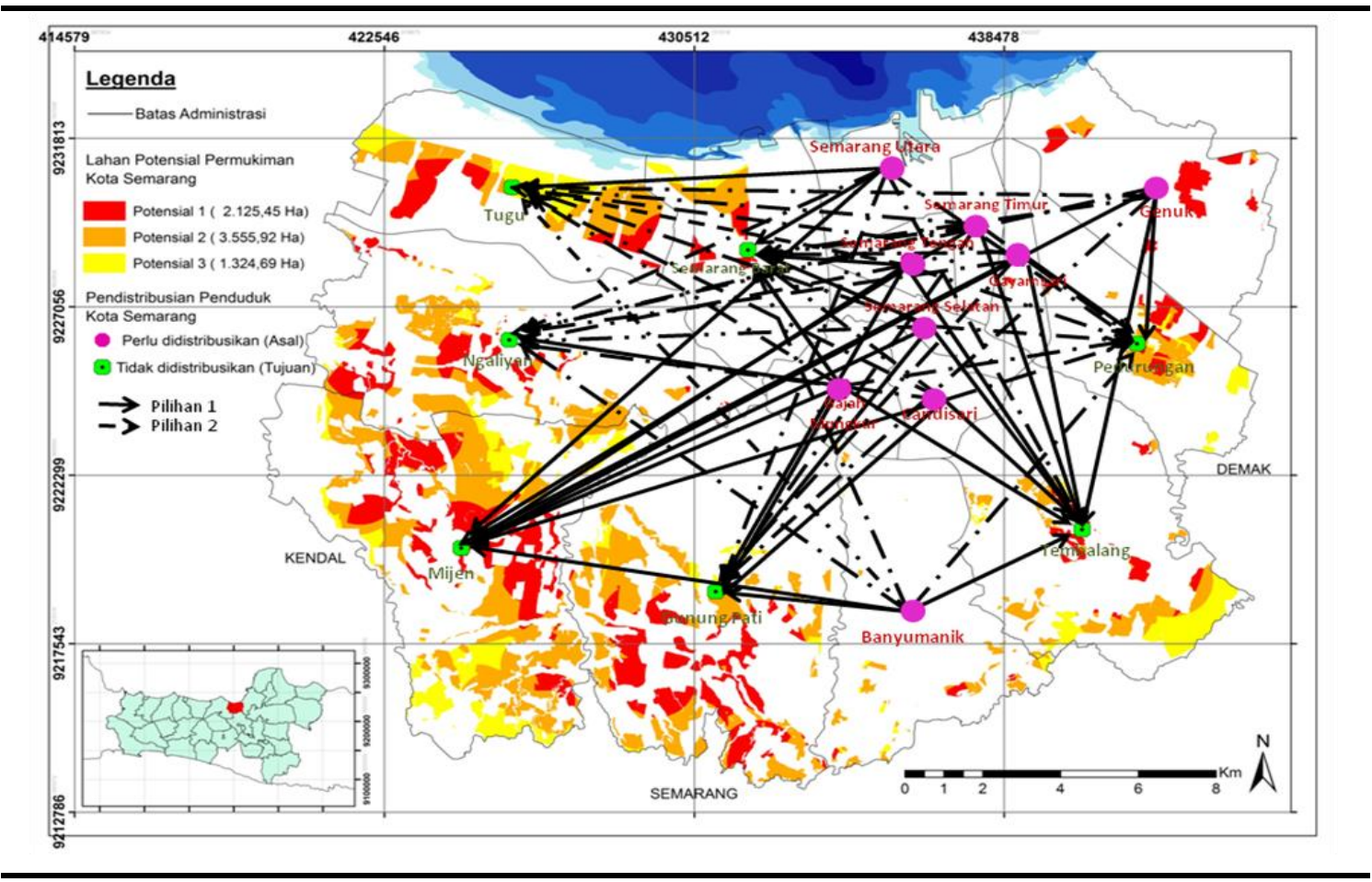

Gambar 3. Peta Arah Distribusi Penduduk di Kota Semarang

\section{KESIMPULAN}

Berdasarkan kajian hasil analisis luas lahan potensial di Kota Semarang yaitu seluas $7.006 \mathrm{Ha}$ atau sekitar 17,98\% dari luas total Kota Semarang yang terbagi menjadi tiga kelas antara lain; cukup potensial (potensial 3), potensial (potensial 2) dan sangat potensial (potensial 1). Lahan potensial tersebut sebagian besarnya berada di daerah pinggiran Kota Semarang dan menjadi lokasi untuk arahan pendistribusian penduduk antara lain tersebar di Kecamatan Semarang Barat, Kecamatan Tugu, Kecamatan Ngaliyan, Kecamatan Mijen, Kecamatan Gunung Pati, Kecamatan Tembalang, dan Kecamatan Pedurungan. Sedangkan kecamatan yang tidak memiliki lahan potensial yaitu sebagian besar kecamatan berada dipusat kota terdiri dari Kecamatan Banyumanik, Kecamatan Gajahmungkur, Kecamatan Gayamsari, Kecamatan Semarang Selatan, Kecamatan Candisari, Kecamatan Genuk, Kecamatan Semarang Timur, Kecamatan Semarang Utara dan Kecamatan Semarang Tengah. Untuk pendistribusian penduduk dari kecamatan yang memiliki lahan potensial ke kecamatan yang tidak memiliki lahan potensial tersebut terdiri dari dua pilihan yaitu pilihan 1 (P1) dan pilihan 2 (P2), namun yang disarankan yaitu yang terkategori ke P1 dikarenakan telah dianalisis berdasarkan kelas lahan potensial, luas lahan potensial dan jarak antar pusat kecamatan. Secara umum luas lahan potensial permukiman di Kota Semarang masih bisa memenuhi kebutuhan lahan permukiman penduduk untuk 20 tahun yang akan datang. 


\section{DAFTAR PUSTAKA}

Aburas, M. M., Abdullah, S. H. O., Ramli, M. F., \& Asha'Ari, Z. H. (2017). Land Suitability Analysis of Urban Growth in Seremban Malaysia, Using GIS Based Analytical Hierarchy Process. Procedia Engineering, 198(September 2016), 1128-1136. https://doi.org/10.1016/j.proeng.2017.07.155

Baja, S. (2012). Perencanaan Tata Guna Lahan dalam Pengembangan Wilayah; Pendekatan Spasial dan Aplikasinya. Yogyakarta: ANDI.

Bank, W. (2016). Kisah Urbanisasi Indonesia. Retrieved July 24, 2018, from http://www.worldbank.org/in/news/feature/2016/06/14/indonesia-urban-story

BPS. (2018). Kota Semarang Dalam Angka 2018. Retrieved August 29, 2018, from https://semarangkota.bps.go.id/

Broitman, D., \& Koomen, E. (2015). Computers , Environment and Urban Systems Residential density change:Densification and urban expansion. Computers, Environment And Urban Systems, 54, 32-46. https://doi.org/10.1016/j.compenvurbsys.2015.05.006

Catanese, A. J., \& Snyder, J. C. (1998). Urban Planning (2nd ed.). New York: McGraw-Hill.

Chi, G., \& Ho, H. C. (2018). Population stress: A spatiotemporal analysis of population change and land development at the county level in the contiguous United States, 2001-2011. Land Use Policy, 70(March 2017), 128-137. https://doi.org/10.1016/j.landusepol.2017.10.008

Handayani, W., \& Rudiarto, I. (2011). Dinamika Persebaran Penduduk Jawa Tengah: Perumusan Kebijakan Perwilayahan Dengan Metode Kernel Density. Universitas Diponegoro. Retrieved from http://eprints.undip.ac.id/35618/

La, P., Barbarossa, L., Ignaccolo, M., Inturri, G., \& Martinico, F. (2011). The density dilemma . A proposal for introducing smart growth principles in a sprawling settlement within Catania Metropolitan Area. Cities, 28(6), 527-535. https://doi.org/10.1016/j.cities.2011.06.009

Lee, Y., Montgomery, C. A., \& Kline, J. D. (2016). Landscape and Urban Planning The influence of age-specific migration on housing growth in the rural Midwest ( USA ). Landscape and Urban Planning, 148, 68-79. https://doi.org/10.1016/j.landurbplan.2015.12.005

Muta'ali Lutfhi. (2012). Daya dukung lingkungan untuk perencanaan pengembangan wilayah. Yogyakarta: Badan Penerbit Fakultas Geografi, Universitas Gadjah Mada.

Muta'ali Lutfhi. (2015). Teknik Analisis Regional. Yogyakarta: Badan Penerbit Fakultas Geografi (BPFG) UGM.

Nugraha, Y. K., Nugraha, A. L., \& Wijaya, A. P. (2014). Pemanfaatan SIG untuk menentukan Lokasi Potensial Pengembangan Kawasan Perumahan dan Permukiman (Studi Kasus Kabupaten Boyolali). Jurnal Geodesi Undip Oktober 2014, 4(April), 267-276., $\quad 3(4), \quad$ 50-59. https://doi.org/10.1016/j.ijnurstu.2011.01.003

Pigawati, R. N. B. (2015). Kajian Karakteristik Kawasan Pemukiman Kumuh Di Kampung Kota ( Studi Kasus: Kampung Gandekan Semarang ). Jurnal Teknik PWK, 4(2), 267-281. Retrieved from http://ejournals1.undip.ac.id/index.php/pwk

Prayitno, B., Alfredo, \& Mahdatia, P. (2012). Perlindungan Hak Bermukim MBR dan Warga Miskin Perkotaan. Jakarta: : Kementerian Koordinator Kesejahteraan Rakyat.

Pupitasari, N., \& Pradoto, W. (2013). Faktor yang Mempengaruhi Guna Lahan dan Pola Perkembangan Permukiman Kawasan Pinggiran (Studi Kasus: Daerah Geda ang, Kota Semarang). Jurnal Teknik PWK, 2(3), 638-648.

Samsidar, Y., Dewi, I. K., Wirawan, B., Lahan, K., Gedongtataan, K., \& Padang, K. (2012). Daya Dukung Lahan Untuk Pengembangan Kawasan Permukiman Perkotaan Di Kabupaten Pesawaran Provinsi Lampung. Program Studi Perencanaan Wilayah Dan Kota, FT-Unpak, 4, 1-8.

Satria, M., \& Rahayu, S. (2013). Evaluasi Kesesuaian Lahan Permukiman Di Kota Semarang Bagian Selatan. Jurnal Teknik PWK, 2(1), 160-167. Retrieved from http://ejournal-s1.undip.ac.id/index.php/pwk

Setyowati, D. L. (2007). Kajian Evaluasi Kesesuaian Lahan Permukiman Dengan Teknik Sistem Informasi

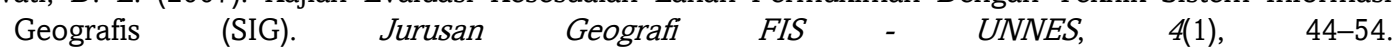
https://doi.org/https://doi.org/10.15294/jg.v4i1.111

SK Menteri Pertanian No 837/KPTS/UM/11/1980 Tentang Kriteria Dan Tata Cara Penetapan Hutan Lindung.

SNI-1728-1989 Tata Cara Pemilihan Lokasi Prioritas Untuk Pengembangan Perumahan Dan Permukiman di Kawasan Perkotaan. (n.d.).

Sriwinarti, A. (2005). Beberapa Karakteristik Umum Pertumbuhan Enam Kota Besar Di Indonesia Tahun 1980 2000. Economic Journal of Emerging Markets, 10, 67-79. Retrieved from http://www.journal.uii.ac.id/index.php/JEP/article/view/606 
Susanti, R., Soetomo, S., Buchori, I., \& Brotosunaryo, P. M. (2016). Smart growth , smart city and density : in search of the appropriate indicator for residential density in Indonesia. Procedia - Social and Behavioral Sciences, 227(November 2015), 194-201. https://doi.org/10.1016/j.sbspro.2016.06.062

Syukur, M. (2013). Analisa Ketersediaan Lahan Bagi Pertumbuhan Penduduk Perkotaan Menggunakan Sistem Informasi Geografis. TeknikA, https://doi.org/https://dx.doi.org/10.1177/0145721717706417

Umar, I., Pramudya, B., Geografi, P. S., Ilmu, F., Unp, S., \& Airtawar, K. (2017). Evaluasi Kesesuaian Lahan Permukiman Dengan Metode Multi Criteria Evaluation Di Kota Padang. Jurnal Pengelolaan Sumberdaya Alam Dan Lingkungan, 72), 148-154. https://doi.org/10.19081/jpsl.2017.7.2.148 